\title{
KINERJA APARATUR TERHADAP PELAYANAN PUBLIK DI KANTOR DESA TIMORENG PANUA KECAMATAN PANCA RIJANG KABUPATEN SIDENRENG RAPPANG
}

\author{
Asri Jide \\ IImu Pemerintahan, Fakultas IImu Sosial dan IImu Politik, Universitas Muhammadiyah Sidenreng Rappang \\ asriacci705@gmail.com
}

\begin{abstract}
Abstrak
Penelitian ini bertujuan untuk mengetahui kinerja aparatur di kantor Desa Timoreng Panua, pelayanan publik di kantor Desa Timoreng Panua dan kinerja aparatur terhadap pelayanan publik di kantor Desa Timoreng Panua Kecamtan Panca Rijang Kabupaten Sidenreng Rappang. Populasi dalam penelitian ini adalah 547 Kepala Keluarga yang dimana pengambilan Sampel yang digunakan yaitu Probability Sampling, dengan teknik sampling acak/random sampling dengan menggunakan Rumus Yount $10 \%$ dengan jumlah Sampel 55 Kepala Kelurga, Penelitian ini menggunakan Metode Deksriptif Kuantitatif. Teknik Pengumpulan data yang digunakan melalui Observasi, Kuesioner, dan Dokumentasi. Teknik Analisis data yang digunakan adalah analisis tabulasi frekuensi, dan analilis regresi linear dengan menggunakan SPSS 21.0 for windows. Hasil penelitian ini menunjukkan bahwa rata-rata persentase kinerja aparatur di kantor Desa Timoreng Panua Kecamatan Panca Rijang Kabupaten Sidenreng Rappang sebesar 56,25\% dengan kategori cukup baik, pelayanan publik di kantor Desa Timoreng Panua Kecamatan Panca Rijang Kabupaten Sidenreng Rappang sebesar $65,52 \%$ dengan kategori baik kinerja aparatur terhadap pelayanan publik di kantor Desa Timoreng Panua Kecamatan Panca Rijang Kabupaten Sidenreng Rappang sebesar 20,2 \% dengan kategori tidak berpengaruh.
\end{abstract}

Kata Kunci : Kinerja, Pelayanan public

\begin{abstract}
This study aims to determine the performance of the apparatus in the Timoreng Panua Village office, public services at the Timoreng Panua Village office and the performance of the apparatus for public services in the Timoreng Village office, Panua, Panca Rijang Subdistrict, Sidenreng Rappang District. The population in this study was 547 heads of households whose sampling was used, namely probability sampling, with random sampling using a Yount formula of $10 \%$ with a sample of 55 heads of families, this study used a quantitative descriptive method. Data collection techniques used through observation, questionnaires, and documentation. Data analysis techniques used were frequency tabulation analysis, and linear regression analysis using SPSS 21.0 for windows. The results of this study indicate that the average percentage of apparatus performance in the Timoreng Village office in Panua, Panca Rijang District, Sidenreng Rappang Regency was $56.25 \%$ with a fairly good category, public services in the Timoreng Panua Village office in Panca Rijang District, Sidenreng Rappang District at $65.52 \%$ with a good category of apparatus performance on public services in the Timoreng Panua Village office, Panca Rijang District, Sidenreng Rappang Regency, at 20.2\% with no effect category.
\end{abstract}

Keywords: Performance, Public Services

PRAJA | Volume 8| Nomor 1| Edisi Februari 2020 


\section{A. PENDAHULUAN}

Menurut UU No 6 Tahun 2014 Tentang Desa adalah desa dan desa adat atau biasa disebut dengan nama lainnya, selanjutnya disebut desa, adalah kesatuan masyarakat hukum yang memiliki batas wilayah yang berwenangan untuk mengatur dan mengurus urusan pemerintahan, kepentingan masyarakat setempat berdasarkan prakarsa masyarakat, hak asal-usul, dan/atau hak tradisional yang diakui dan dihormati dalam sistem pemerintahan Negara Republik Indonesia. Undang-Undang Nomor 23 Tahun 2014 Tentang Pemerintahan Daerah, Pemerintahan daerah merupakan kepalah daerah sebagai unsur penyelenggara Pemerintah Daerah yang menjadi kewenangan daerah otonom. Sedangkan Pemerintahan Daerah adalah penyelenggaraan urusan pemerinth oleh pemerintah daerah dan Dewan Perwakilan Rakyat Daerah menurut asas otonomi dan tugas pembantuan dengan prinsip otonomi selua-luasnya dalam sistem dan prinsip Negara Republik Indonesia sebagaimana dimaksud dalam Undang-Undang Dasar Negara Republik Indonesia Tahun 1945.

Pemerintah Desa atau yang disebut dengan nama lain adalah Kepala Desa dan Parangkat Desa sebagai unsur penyelenggara pemerintahan desa. Dari penegasan peraturan perundang-undangan jelas bahwa Desa merupakan unit pemerintah terendah yang diakui dalam system penyelenggaraan pemerintahan nasional. Ini dapat berarti bahwa Pemerintah Desa merupakan organisasi pemerintah terdepan di dalam penyelenggaraan pelayanan publik, oleh karena itu, Pemerintah Desa dituntut untuk dapat meningkatkan kinerjanya di dalam penyelenggaraan pelayanan publik sesuai dengan harapan masyarakat. Berkaitan dengan ketentuan tersebut, hal ini mengisyaratkan bahwa dalam melaksanakan urusan rumah tangga desa, melakukan pembinaan, pembangunan masyarakat, dan membina perekonomian desa harus dapat dijalankan oleh aparatur desa karena masyarakat desa telah berkembang dengan berbagai kegiatan yang semakin membutuhkan aparatur pemerintah yang professional.

Keberhasilan dalam sebuah organisasi tidak terlepas dari kemampuan sumber daya manusia para individu yang bekerja di dalamnya. Baik organisasi pemerintah maupun organisasi swasta membutuhkan sumberdaya manusia yang memiliki kinerja optimun untuk mendukung tercapainya suatu tujuan yang telah di tetapkan oleh organisasi. Pegawai yang cakap, mampu, dan terampil belum menjamin bahwa pegawai tersebut memiliki kinerja yang baik, kinerja pegawai adalah hasil kualitas dan kuantitas yang dicapai oleh seseorang pegawai dalam melaksanakan tugas yang diberikan kepadanya. Pegawai yang mampu mencapai hasil kerja yang dapat dipertanggungjawabkan kualitas maupun kuantitas dan bekerja secara efektif dan efisie, menunjukkan bahwa pegawai dapat memanfaatkan waktu dan mempergunakan alat-alat dengan baik.

Kinerja pegawai merupakan hal penting yang harus perhatikan oleh setiap instansi, tidak terkecuali di kantor Desa Timoreng Panua Kecamatan Panca Rijang Kabupaten Sidenreng Rappang, karena kinerja pegawai mempengaruhi keberhasilan instansi tersebut dalam mencapai tujuannya.

Kinerja adalah hasil atau tingkat keberhasilan seseoranng secara keseluruhan selama periode tertentu di dalam melaksanakan tugas di bandingkan dengan berbagai kemungkin, seperti standar hasil kerja, target atau sasaran atau kriteria yang telah di tentukan terlebih dahulu dan di sepakati bersama. Pelayanan publik merupakan tanggung jawab pemerintah atas kegiatan yang ditunjukkan untuk kepentingan publik. Tugas pokok aparatur pemerintah pada hahikatnya adalah memberikan pelayaan kepada masyarakat dalam rangka meningkatkan kesejahteraan masyarakat. Pelayanan merupakan utama bagi pegawai sebagai abdi negara dan abdi masyarakat. Tugas ini secara jelas telah digariskan dalam pembukaan UUD 1945 alinea 4, yang meliputi 4 aspek pelayanan pokok pegawai terhadap masyarakat yang berbunyi melindungi segenap bangsa dan seluruh tumpah darah Indonesia memajukan kesejahteraan umum dan mencerdaskan kehidupan bangsa.

Keberhasilann suatu organisasi dipengaruhi oleh kinerja para pegawainya atau hasil kerja yang dicapai oleh para pegawai dalam melakukan tugas sesuai dengan tanggung jawab yang diberikan kepadanya Pegawai merupakan sumber daya yang penting bagi organisasi, karena memiliki bakat, tenaga, dan kreatifitas yang 
sangat dibutuhkan oleh organisasi untuk mencapai tujuannya.

Konteks negara moderen, pelayanan publik telah menjadi lembaga dan profesi yang semakin penting. la tidak lagi merupakan aktifitas sambilan, tanpa payung hukum, gaji dan jaminan sosial yang memadai, sebagaimana yang terjadi di banyak negara berkembang pada masa lalu. Sebagai sebuah lembaga pelayanan publik menjamin keberlangsungan administrasi negara, yang melibatkan pengembangan kebijakan pelayanan dan pengelolaan sumber daya yang berasal dari dan untuk kepentingan publik.

Pelayanan publik berpijak pada prinsipprinsip profesionalisme dan etika seperti akuntabilitas, efektifitas, efisiensi, integritas, netralitas, dan keadilan bagi semua penerima pelayanan. Dalam perusahaan publik mupun instansi pemerintah, terwujudnya pelayanan publik yang berkuyalitas merupakan salah satu ciri dari pemerintah yang baik sebagai tujuan dari pendayagunaan aparatur negara, dalam kaitan inilah maka poeningkatan kualitas pelayanan publik merupakan suatu upaya yang harus dilakukan secara terus menerus, berkelanjutan dan nharus dilaksanakan oleh semua para aparatur pemerintah.

Pelayanan publik merupakan tanggung jawab pemerintah atas kegiatan yang ditunjukkan untuk kepentingan publik. Tugas pokok aparatur pemerintah pada hahikatnya adalah memberikan pelayaan kepada masyarakat dalam rangka meningkatkan kesejahteraan masyarakat. Pelayanan merupakan utama bagi pegawai sebagai abdi negara dan abdi masyarakat. Tugas ini secara jelas telah digariskan dalam pembukaan UUD 1945 alinea 4, yang meliputi 4 aspek pelayanan pokok pegawai terhadap masyarakat yang berbunyi melindungi segenap bangsa dan seluruh tumpah darah Indonesia memajukan kesejahteraan umum dan mencerdaskan kehidupan bangsa.

Undang-undang Republik Indonesia Nomor 15 Tahun 2014 tentang pedoman standar pelayanan, pelayanan publik merupakan salah satu tugas penting yang tidak dapat diabaikan oleh pemerintah daerah sebab jika kompenen pelayanan tidak aktif maka hampir dipastikan semua sektor akan berdampak kemacetan oleh sebab itu perlu ada perencanaan yang baik dan bahkan perlu dipermulasikan standar pelayanan pada masyarakat sesuai dengan kewenangan yang diberikan oleh pemerintah pusat pada pemerintah daerah. Pemerintahan daerah diberi kewenangan yang demikian luas oleh pemerintah pusat untuk mengatur rumah tangga daerahnya sendiri, termasuk didalamnya adalah pemberian pelayanan kepada masyarkat di daerahnya.

Konsep kinerja yang ideal terdapat 3 bentuk kinerja yang di kemukakan oleh Mangkunegara dalam (Sellang, 2016) yaitu :

a. Kualitas kerja,

b. Kuantitas kerja,

c. Waktu kerja.

Menurut Mangkunegara dalam (Zainuddin, 2017) kinerja merupakan prestasi kerja atau hasil kerja baik kualitas maupun kuantitas yaang di capai dan di hasilkan sumberdaya manusia persatuan periode waktu dalam melaksanakan tugs kerjanya sesui dengan tanggung jawab diberikan kepadanya. Kinerja juga mempunyai makna yang lebih luas bukan hanya menyatakan sebgai hasil kerja, tetapi juga bagaimna proses berlansung. Dalam hal ini kinerja adalah proses melakukan pekerjaan dengan hasil dari pekerjaan tersebut.

Menurut Sutopo dan Suryanto dalam (Hayat, 2017) memberikan pelayanan yang terbaik bagi masyarakat adalah bagian dari tanggung jawab yang wajib dipenuhi oleh aparatur. Salah satu unsur dari kepuasan terhadap pelayanan bagi masyarakat adalah pelayanan yang baik dan prima. Sementara itu, pelayanan yang baik adalah pelayanan yang berdasar pada kebutuhan dan kepentingan masyarakat. Penerima layanan merasa terhormat, nyaman, aman, dan tentunya diberikan yang terbaik sesuai dengan pelayanan yang diharapkan.

Berdasarkan observasi awal di Desa Timoreng Panua Kecamatan Pancarijang Kabupaten Sidenreng Rappang masalah yang dijumpai penulis yaitu pelayanan yang diberikan oleh aparat pemerintah Desa Timoreng Panua Kecamatan Pancarijang Kabupaten Sidenreng Rappang masih jauh dari kata memuaskan, khususnya pelayanan dalam pembuatan surat menyurat serta persoalan-persoalan dimasyarakat masih banyak ditemui keluhan-keluhan dimasyarakat, keluhan tersebut diperoleh dari warga desa yang hendak mengurus suratsurat keterangan di kantor desa, tetapi tidak bisa dilayani karena seringkali tidak ada 
perangkat desa yang hadir hal ini dikarenakan perangkat desa yang bersangkutan terlambat masuk kantor atau bahkan pulang lebih awal dari jadwal yang seharusnya. Produktivitas layanan yaitu efesiensi dan efektivitas layanan publik ini belum dapat dicapai, demikianpula dengan hasil capaian kerja dalam menyelenggarakan pelayanan publik khususnya masyarakat Desa Timoreng Panua Kecamatan Pancarijang Kabupaten Sidenreng Rappang yang menjadi kewenangan desa belum sepenuhnya maksimal dilaksanakan. Aparatur pemerintah desa juga seringkali masih bingung dengan cara pengoprasian computer sehingga waktu penyelesaiannya dalam memberikan layanan tidak menentu.

Berdasarkan uraian di atas, maka penulis tertarik untuk mengadakan penelitian dengan judul "Kinerja Aparatur terhadap Pelayaan Publik di Desa Timoreng Panua Kecamatan Panca Rijang Kabupaten Sidenreng Rappang dengan tujuan Untuk mengetahui kinerja aparatur di Desa Timoreng Panua Kecamatan Panca Rijang Kabupaten Sidenreng Rappang, Untuk mengetahui palayanan publik di Desa Timoreng Panua Kecamatan Panca Rijang Kabupaten Sidenreng Rappang dan Untuk mengetahui kinerja aparatur terhadap pelayanan publik di Desa Timoreng Panua Kecamatan Panca Rijang Kabupaten Sidenreng Rappang.

\section{Kinerja}

Istilah kinerja berasal dari job perfonmance atau actual performance (prestasi kerja atau prestasi sesungguhnya yang di cpai oleh seseorang). Menurut Amstrong dan Barrong dalam (Sellang, 2016) kinerja merupakan hasil pekerjaan yang mempunyai hubungan kuat dengan tujuan strategi oranisai, kepuasan konsumen, dan memberikan kontribusi pada ekonomi. Menurut Rivai dalam (Yusuf Wildan Setiyadi, 2017) bahwa kinerja merupakan perilaku yang nyata yang ditampilkan setiap orang sebagai prestasi kerja yang dihasilkan oleh pegawai sesuai dengan perannya dalam perusahaan.Menurut Mangkunegara dalam (Zainuddin, 2017) kinerja merupakan prestasi kerja atau hasil kerja baik kualitas maupun kuantitas yaang di capai dan di hasilkan sumberdaya manusia persatuan periode waktu dalam melaksanakan tugas kerjanya sesui dengan tanggung jawab diberikan kepadanya. Kinerja juga mempunyai makna yang lebih luas bukan hanya menyatakan sebgai hasil kerja, tetapi juga bagaimna proses berlansung. Dalam hal ini kinerja adalah proses melakukan pekerjaan dengan hasil dari pekerjaan tersebut.

Rue \& Yars dalam (Pasolong, 2013) menyatakan bahwa kinerja adalah sebgai tingkat pencapaian hasil. Kinerja menurut interplan adalah berkaitan dengan operasi, aktivitas, programm dan misi organisasi. Kinerja dalam suatu organisi, terkhusus pada organisasi publik (pemerintahan), dapat diliat dari sudut pandang yaitu : kinerja organuisasi itu sendri (kinerja keuangan) dan kinerja pegawai. Baik buruknya kinerja pegawai akan berpengaru terhadap kinerja organisasi itu sendiri (Hasbar, 2014).Whitnore dalam (Uno, 2014) kinerja adalah pelaksaan fungsi-fungsi yang dituntut dari seseorang. Pengertian yang menurut Whitmore meruoakan pengertian yang menuntut kebutuhan yang paling minim untuk berhasil, oleh karenana itu Whitmore mengatakan pengertian kinerja yang dianggapnya representatif, maka tergambarnya tanggung jawab yang besar dari pekerjaan seseorang. Sedangkan menurut Simamora dalam(Uno, 2014) kinerja adalah keadaan atau tingkat perilaku seseorang yang harus di capai persyaratan tertentu. Kinerja adalah nilai yang di perole dari suatu perilaku aparatur baik secara fositif maupun negatif, untuk mencapai tujuan organisasi.Menurut Miner (Sudarmanto, 2009) mengemukakan 4 dimensi yang dijadikan sebagai tolak ukur dalam menilai kinerja, yaitu : 1. Kualitas, 2. Kuantitas 3. Penggunaan waktu dalam bekerja, 4. Kerja sama dengan orang lain.

a) Kualitas kerja. Kualitas kerja adalah ukuran seberapa baik seprang karyawan dalam mengerjakan apa yang seharusnya ia kerjakan. Menunjukkan kerapihan, ketelitian, keterkaitan hasil kerja dengan tidak mngabaikan volume pekerjaan. Kualitas kerja yang baik dapat menghindari tingkat keselahan dalam penyelesaian suatu pekerjaan yang dapat bermamfaat bagi kemajuan perusahaan (Mangkunegara, 2013).

b) Kuantitas kerja. Kuantitas adalah sesuatu hal yang berbentuk dari proses pengukuran. Mangkunegara kuantitas kerja ukuran seberapa lama seorang 
karyawan dapat bekerja dalam satu harinya.

c) Penggunaan waktu dalam bekerja. Kemampuan organisasi untuk menetapkan waktu kerja yang di anggap paling efesien dan efektif pada semua level dalam manajemen. Waktu kerja merupakan dasar bagi seorang karyawan dalam menyelesikan suatu pekerjaan atau layanan yang menjadi tanggung jawabnya.

d) Kerja sama. Kerja sama merupakan tuntutan bagi keberhasilan perusahaan dalam mencapai tujuan yang ditetapkan, sebab dengan adanya kerja sama yang baik akan memberikan kepercayaan (trust) pada berbagai pihak yang berkepentingan, baik secara langsung maupun tidak langsung.

\section{Pelayanan Publik}

Menurut Sampara(Pratama, 2015) adalah suatu kegiatan atau urutan kegiatan yang terjadi dalam interaksi langsung antar seseorang dengan orang lain atau mesin secara fisik, dan menyediakan kepuasan pelanggan. Sedangkan menurut Kotler dalam (Pratama, 2015) pelayanan adalah setiap kegiatan yang menguntungkan dalam suatu kumpulan atau kesatuan, dan menawarkan kepuasan meskipun hasilnya tidak terikat pada suatu produk secara fisik.Menurut Keban dalam (Zainuddin, 2017) mengatakan bahwa dalam arti yang sempit, pelayanan publik adalah suatu tindakan pemberian barang dan jasa kepada masyarakat oleh pemerintah dalam rangka tanggung jawabnya kepada publik, baik diberikan secara langsung maupun melalui kemitraan dengan swasta dan masyarakat, berdasarkan jenis dan intensitas kebutuhan masyarakat, kemampuan masyarakat dan pasar. Konsep ini lebih menekankan bagaimana pelayanan public berhasil diberikan melalui suatu delivery system yang sehat. Dalam arti luas, konsep pelayanan public identik dengan administrasi public yaitu berkorban atas nama orang lain dalam mencapai kepentingan publik.

Menurut (Sinambela, 2014) pelayanan adalah kegiatan untuk memenuhi kebutuhan seseorang atau menyediakan keperluan orang. Pelayanan juga merupakan suatu kegiatan atau urutan kegiatan yang terjadi dalam interaksi langsung antar seseorang dengan orang lain atau mesin secara fisik dan menyediakan kepuasan pelanggan.
Pelayanan sebagai hal, cara, atau hasil pekerjaan yang melayani.Ratminto \& Winarsih dalam (Jamaluddin, 2016) mengartikan : "Pelayanan sebagai suatu aktivitas atau serangkaian aktivitas yang bersifat tidak kasat mata (tidak dapat diraba) yang terjadi sebagai akibat adanya interaksi antara konsumen dengan karyawan atau halhal lain yang disediakan.Pelayanan publik dapat diartikan sebagai pemberian layanan (melayani) keperluan orang atau masyarakat yang mempunyai kepentingan pada organisasi itu sesuai dengan aturan pokok dan tata cara yang telah ditetapkan. Pemerintahan pada hakekatnya adalah pelayanan kepada masyarakat, Tidak dapat untuk melayani dirinya sendiri, tetapi untuk melayani masyarakat serta menciptakan kondisi yang memungkinkan setiap anggota masyaraakat mengembangkan kemampuan dan kreativitasnya demi mencapai tujuan bersama.

a) Peraturan Pemerintah nomor 2 tahun 2018 tentang Standar Pelayanan Minimal. Pelayanan publik terutama pemenuhan hak dasar masyarakat yang mencakup sosial, ekonomi dan pemerintahan menjadi agenda utama pemerintah, sehingga perlu diciptakan sebuah instrumen/standar yang bisa menjadi indikator pencapaian dan pemenuhan hak dasar tersebut oleh pemerintah. Birokrasi publik berkewajiban dan bertanggung jawab untuk memberikan layanan yang baik dan professional, karena dengan proses pelayanan yang lebih cepat dan berkualitas merupakan tuntutan bagi pemerintah sebagai penyedia layanan sekaligus pelayanan yang berkualitas adalah dambaan dan harapan seluruh masyarakat yang memenuhi kebutuhannya. Menurut Zeithhaml dkk dalam (Pasolong, 2011) ada lima indikator untuk mengetahui kualitas pelayanan yang dirasakan secara nyata oleh konsumen yaitu Bukti fisik (Tangibles) yaitu kualitas pelayanan yang berupa sarana fisik perkantoran, komputerisasi administrasi, ruang tunggu, tempat ninformasi. Penyediaan sumber daya manusia dan sumber daya lainnya yang memadai.

b) Keandalan (Reability) yaitu kemampuan dan keandalan untuk menyediakan pelayanan yang terpercaya. Pelayanan 
publik memberikan pelayanan secara tepat dan benar.

c) Daya Tanggap (Resvonsiviness) yaitu kesanggupan untuk membantu dan menyediakan pelayanan secara cepat dan tepat, serta tanggap terhadap keinginan konsumen.

d) Jaminan (Assurance) adalah kemampuan dan keramahan serta sopan santun pegawai dalam meyakinkan kepercayaan konsumen.

e) Empati (Empathy) adalah sikap tegas dan penuh perhatian dari pegawai terhadap konsumen. Tingkat kemauan untuk mengetahui keinginan dan kebutuhan masyarkat.

\section{B. METODE PENELITIAN}

Penelitian ini direncanakan dilaksanakan di Desa Timoreng Panua Kecamatan Panca Rijang Kabupaten Sidenreng Rappang dan dilaksanakan selama 2 (dua) bulan lamanya mulai 30 April sampai 30 Mei 2019. Tipe penelitian ini adalah deskriptif dengan menggunakan pendekatan kuantitatif yaitu yang bertujuan untuk menggambarkan permasalahan secara sistematis, faktual dan aktual yang terjadi di lokasi penelitian yaitu menjelaskan tentang kinerja aparatur terhadap peningkatan kualitas pelayanan publik di Desa Timoreng Panua Kecamatan Panca Rijang Kabupaten Sidenreng Rappang.Adapun populasi adalah seluruh kepala keluarga yang ada di Desa Timoreng Panua sebanyak 547 kepala keluarga. Pengambilan sampel yang digunakan pada penelitian ini adalah probability Sampling, yaitu teknik pengambilan sampel yang memberikan peluang, probabilitas atau kesempatan yang sama bagi setiap anggota populasi untuk dipilih menjadi sampel. Teknik Pengambilan sampel ini penulis menggunakan teknik sampel acak/random sampling, yaitu pengambilan anggota sampel dari populasi dilakukan dengan cara acak tanpa memandang strata yang ada pada populasi. Selanjutnya teknik pengambilan sampel dengan tingkat kesalahan $10 \%$ menggunakan rumus Yount sebanyak $55 \mathrm{KK}$ yang dijadikan sebagai responden.

Teknik pengumpulan data dalam penelitian ini menggunakan empat teknik, yaitu Observasi, Kuesioner atau angket, dan Study kepustakaan (library research) sedangkan Teknik Analisis data yang digunakan adalah analisis tabulasi frekuensi, dan analilis regresi linear dengan menggunakan SPSS 21.0 for windows.

\section{HASIL DAN PEMBAHASAN}

1. Kinerja

Rekapitulasi tanggapan tentang inidikator kinerja

\begin{tabular}{|c|c|c|}
\hline No & $\begin{array}{l}\text { Tangggapan } \\
\text { Responden }\end{array}$ & Persentase \% \\
\hline 1 & Kualitas Kerja & $72 \%$ \\
\hline 2 & Kuantitas Kerja & $66 \%$ \\
\hline 3 & Waktu Kerja & $33 \%$ \\
\hline 4 & Kerja Sama & $54 \%$ \\
\hline & Jumlah & $56,25 \%$ \\
\hline
\end{tabular}

Tabel di atas terdapat empat indikator dalam kinerja yang digunakan oleh peneliti. Adapun indikator pertama adalah kualitas kerja yaitu ukuran seberapa baik seorang karyawan dalam mengerjakan apa yang seharusnya ia kerjakan. Kuantitas kerja yaitu peraturan sistem kerja yang dibuat menjadi pedoman yang dipatuhi dengan baik dan benar. Indikator ketiga adalah waktu kerja yaitu waktu kerja yaitu dasar bagi seorang karyawan dalam menyelesikan suatu pekerjaan atau layanan yang menjadi tanggung jawabnya. Indikator keempat adalah kerja sama yaitu tuntutan bagi keberhasilan perusahaan dalam mencapai tujuan yang ditetapkan, sebab dengan adanya kerja sama yang baik akan memberikan kepercayaan (trust) pada berbagai pihak yang berkepentingan, baik secara langsung maupun tidak langsung.

Hasil rekapitulasi indikator kinerja didapatkan hasil $56,25 \%$ dengan kategori cukup baik. Dari keempat indikator tersebut indikator yang paling dominan adalah kualitas kerja yakni $72 \%$, hal ini berarti beberapa kegiatan yang dilakukan oleh aparatur desa dilakukan dengan teliti ataupun dapat memuaskan masyarakat, dan indikator yang paling rendah adalah waktu kerja yakni $33 \%$, berdasarkan informasi yang didapatkan oleh peneliti pada saat pembagian kuesioner bahwa seringnya aparatur desa yang datang terlambat atau pulang di saat masih jam kerja, sehingga terkadang masyarakat yang 
ingin mengurus surat-surat terkendala karena tidak adanya aparatur di kantor.

2. Pelayanan Publik

Rekapitulasi tanggapan responden tentang indikator pelayanan publik

\begin{tabular}{|c|c|c|}
\hline No & $\begin{array}{c}\text { Tanggapan } \\
\text { Responden }\end{array}$ & Persentase \% \\
\hline 1 & Bukti fisik & $66 \%$ \\
\hline 2 & Keandalan & $57 \%$ \\
\hline 3 & Daya tanggap & $70 \%$ \\
\hline 4 & Jaminan & $62 \%$ \\
\hline 5 & Empati & $72,6 \%$ \\
\hline \multicolumn{2}{|c|}{ Jumlah } & $65,52 \%$ \\
\hline
\end{tabular}

Sumber hasil olahan data kusioner 2019

Tabel di atas terdapat lima indikator dalam pelayanan publik yang digunakan oleh peneliti. Indikator pertama adalah bukti fisik yaitu berupa sarana fisik perkantoran, komputerisasi administrasi, ruang tunggu, tempat ninformasi.Indikator kedua adalah keandalan yaitu kemampuan dan keandalan untuk menyediakan pelayanan yang terpercaya. Pelayanan publik memberikan pelayanan secara tepat dan benar. Indikator ketiga adalah daya tanggap yaitu kesanggupan untuk membantu dan menyediakan pelayanan secara cepat dan tepat, serta tanggap terhadap keinginan konsumen. Indikator keempat adalah jaminan yaitu kemampuan dan keramahan serta sopan santun pegawai dalam meyakinkan kepercayaan konsumen. Indikator yang kelima adalah empati sikap tegas dan penuh perhatian dari pegawai terhadap konsumen. Tingkat kemauan untuk mengetahui keinginan dan kebutuhan masyarakat.

Hasil rekapitulasi indiaktor pelayanan publik didapatkan hasil $65,25 \%$ dengan kategori baik. Dari kelima indikator tersebut indikator yang paling dominan adalah indikator empati yakni $72,6 \%$, hal ini hal ini berarti aparatur mampu memberikan pelayanan, mudah melakukan hubungan komunikasi dengan masyarakat tanpa mengabaikan sikap sopan santun dan kemauan memberi pelayanan untuk mendengarkan aspirasi masyarakat, dan indikator yang paling rendah adalah indikator keandalan yakni $57 \%$, hal ini berarti pelayanan dalam menciptakan pelayanan yang dijanjikan kurang konsisten atau melampaui dari waktu yang telah di tentukan.

3. Regresi linear sederhana

Pengaruh kinerja aparatur terhadap pelayanan publik menggunakan olahan data SPSS 21.0 for windows dengan tabel model summary

Tabel 4.12Model Summary

Pengaruh X terhadap Y

Model Summary

\begin{tabular}{|l|r|r|r|r|}
\hline $\begin{array}{l}\text { Mode } \\
\mathrm{I}\end{array}$ & $\mathrm{R}$ & \multicolumn{1}{c|}{$\mathrm{R}$} & \multicolumn{1}{|c|}{$\begin{array}{c}\text { Adjusted R } \\
\text { Square }\end{array}$} & $\begin{array}{r}\text { Std. Error of } \\
\text { the Estimate }\end{array}$ \\
\hline 1 &, $202^{\mathrm{a}}$ &, 041 &, 023 & 2,242 \\
\hline
\end{tabular}

a. Predictors: (Constant), KINERJA

Hasil olahan data 2019

$\mathrm{R}$ adalah $0,202 \times 100 \%=20,2 \%$ (pengaruh $X$ terhadap $Y$ ) sisanya $100 \%-20,2=79,8$.Berdasarkan tabel model summary koefisien determinasi $R=0,202$, berarti kinerja aparatur (X) terhadap pelayanan publik $(Y)$ yaitu $20,2 \%$. Atau dengan kata lain pengaruh variabel bebas terhadap variabel terikat sebesar $20,2 \%$ sedangkan sisanya $79,8 \%$ dipengaruhi oleh variabel lain.

\section{KESIMPULAN}

Berdasarkan hasil penelitian yang telah diuraikan di bab sebelumnya, dapat disimpulkan bahwa :

1. Kinerja aparatur di kantor Desa Timoreng Panua Kecamatan Panca Rijang Kabupaten Sidenreng Rappang sebesar 56,25 dengan kategori cukup baik

2. Pelayanan publik di kantor Desa Timoreng Panua Kecamatan Panca Rijang sebesar $65,25 \%$ dengan kategori baik

3. Pada kinerja aparatur terhadap pelayanan publik di Kantor Desa Timoreng Panua sebesar $20,2 \%$ dengan kategori tidak berpengaruh.

\section{E. REFERENSI}

Ahmad, J. (2015). Metode penelitian Administrasi Publik Teori dan Aplikasinya (G. Media, ed.). Yogyakarta.

Hasbar, M. (2014). Menguak Perilaku Organisasi Sektor Publik Antara Teori Dan Aplikasi. Yogyakarta: Ombak. 
Hayat, H. (2017). Peneguhan Reformasi Birokrasi melalui Penilaian Kinerja Pelayanan Publik. Jurnal IImu Sosial Dan IImu Politik, 20(2), 175. https://doi.org/10.22146/jsp.24804

Jamaluddin, Y. (2016). Model Peningkatan Kualitas Pelayanan Publik.

Mangkunegara, A. P. (2013). Manajemen Sumber Daya Manusia Perusaan. Bandung: Remaja Rosdakarya.

Pasolong, H. (2011). Teori Adminstrasi Publik. Bandung: Alfabeta.

Pratama, M. H. (2015). Strategi Meningkatkan Kualitas Pelayanan Publik (Studi Deskriptif tentang Strategi UPTD Pengujian Kendaraan Bermotor Tandes Kota Surabaya dalam Meningkatkan Kualitas Pelayanan Pengujian Kendaraan Bermotor). IImu Administrasi Negara, 3(3), 90-98.

Sellang, K. (2016). Administrasi Dan Pelayaan Publik. Yogyakarta: Ombak.

Sinambela, L. P. (2014). Reformasi Pelayanan Publik. Jakarta: PT. Bumi Aksara.

Sudarmanto. (2009). Kinerja dan Pengembangan Kompetensi Sumber daya Manusia Teori, Dimensi Pengukuran, Implementasi dalam Organisasi. Yogyakarta: Pustaka Pelajar.

Uno, H. B. (2014). Teori Kinerja dan Pengukurannya. Jakarta: Bumi Aksara.

Yusuf Wildan Setiyadi, $\square$ Sri Wartin. (2017). Pengaruh Kualitas Kehidupan Kerja Terhadap Kinerja Karyawan Dengan Kepuasan Kerja Sebagai Variabel Intervening. Management Analysis Journal, 5(4), 315-324.

Zainuddin. (2017). Teori-Teori Mutakhir Dalam Perspektif lilmu Administrasi Publik. Makassar: Phinatama Media. 